\title{
Teaching NeuroImages: The tetraplegic gardener
}

\section{A case of CNS nocardiosis in an immunocompetent patient}

Victor de Britto Gadelha, MD, Fábio A. Nascimento, MD, Vitor Kobiec Fiamoncini, MD, João Augusto da Silva Freitas, MD, Marcos Christiano Lange, MD, PhD,

Bernardo Corrêa de Almeida Teixeira, MD, Edison M. Novak, MD, and Hélio A. G. Teive, MD, PhD

Neurology ${ }^{\circledR}$ 2019;92:e2840-e2841. doi:10.1212/WNL.0000000000007663

Figure 1 Nocardiosis skin lesions

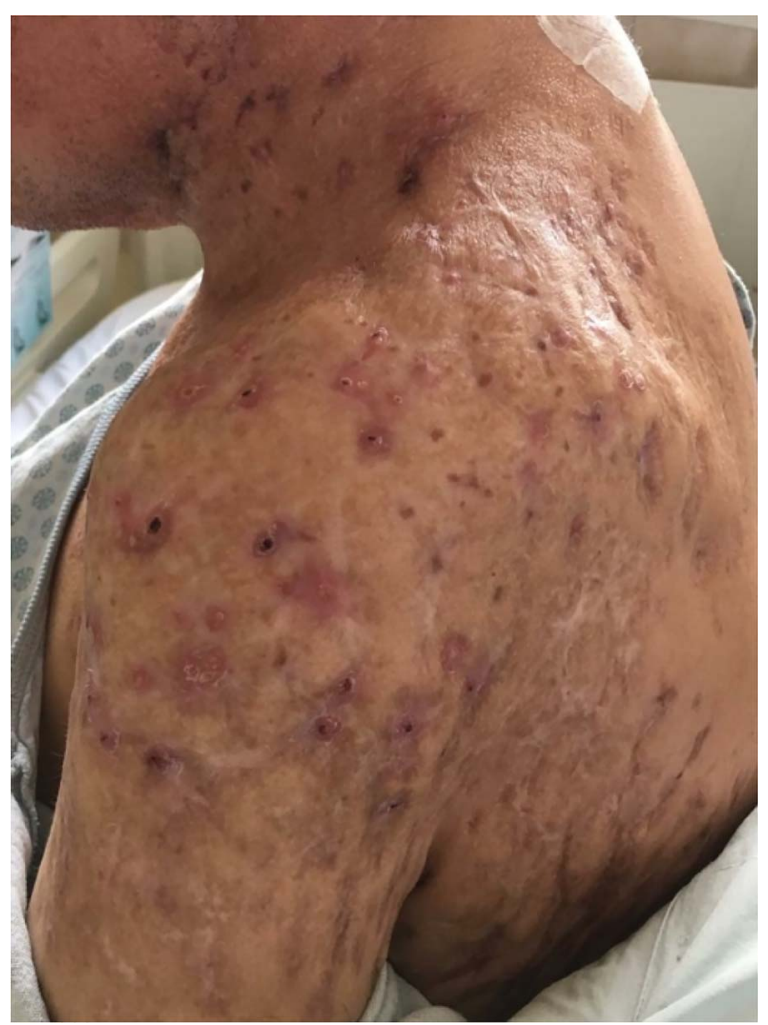

Skin lesions throughout the left upper limb and posterior cervical region.

A 36-year-old immunocompetent male gardener with chronic skin lesions (figure 1) presented with a 6-month history of progressive spastic tetraplegia. Cervical imaging showed soft tissue lesions at the $\mathrm{C} 2$-to-T4 level with extension to the epidural/subdural compartments along with longitudinal intramedullary hyperintensities (figure 2). Skin biopsy revealed Nocardia brasiliensis.

Nocardia brasiliensis is an aerobic, filamentous gram-positive pathogen that typically inhabits the soil-hence its association with gardening. ${ }^{1}$ It generally causes skin infection, mostly in immunocompromised patients. Rarely does nocardiosis affect the CNS; its early recognition, however, is of paramount importance because it guides management and influences prognosis. ${ }^{2}$

\section{Correspondence}

Dr. Gadelha

drvictorgadelha@icloud.com

\section{MORE ONLINE}

\section{$\rightarrow$ Teaching slides}

links.lww.com/WNL/

A903

\section{Study funding}

No targeted funding reported. 


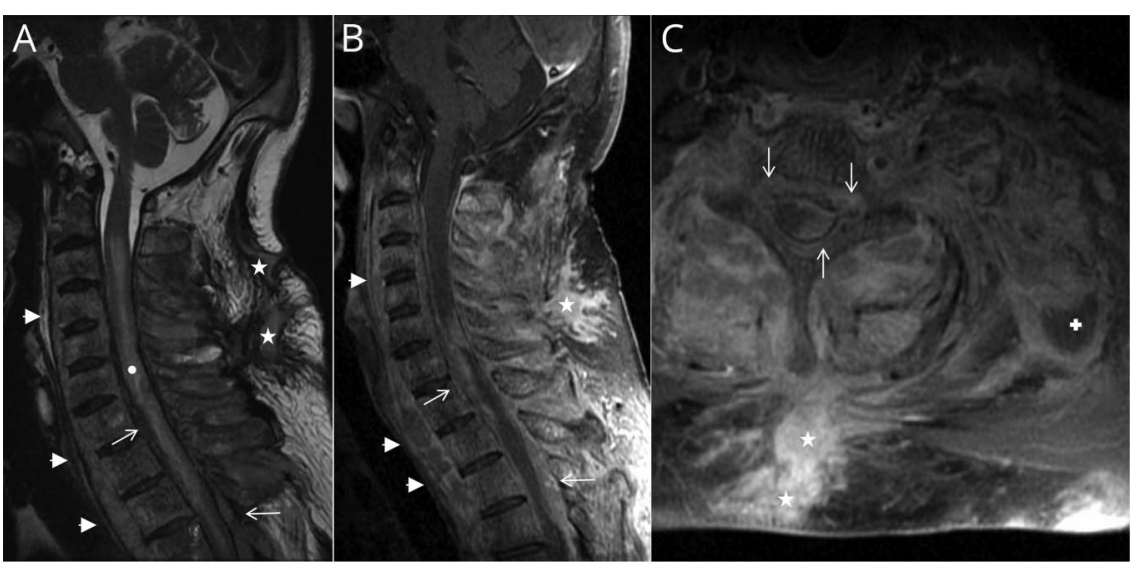

Sagittal T2-weighted RMI image (A) and sagittal (B) and axial (C) T1-weighted images after contrast show multiple epidural collections surrounding the cervical spine (prevertebral: arrowheads; perimedullary: arrows), causing extensive compressive medullary edema (point). Also note a fistula connecting the skin to the spinal canal (star). Peripheral lymphadenopathy is seen (cross).

\section{Disclosure}

The authors report no disclosures relevant to the manuscript. Go to Neurology.org/N for full disclosures.

\begin{tabular}{|c|c|c|c|}
\hline Name & Location & Role & Contribution \\
\hline $\begin{array}{l}\text { Victor de } \\
\text { Britto } \\
\text { Gadelha, MD }\end{array}$ & $\begin{array}{l}\text { Federal } \\
\text { University } \\
\text { of Parana }\end{array}$ & Author & $\begin{array}{l}\text { Study concept and design, } \\
\text { data analysis and } \\
\text { interpretation, and drafting of } \\
\text { the manuscript. }\end{array}$ \\
\hline $\begin{array}{l}\text { Fábio A. } \\
\text { Nascimento, } \\
\text { MD }\end{array}$ & $\begin{array}{l}\text { Baylor } \\
\text { College of } \\
\text { Medicine }\end{array}$ & Author & $\begin{array}{l}\text { Study concept and design, } \\
\text { data analysis and } \\
\text { interpretation, and drafting of } \\
\text { the manuscript. }\end{array}$ \\
\hline $\begin{array}{l}\text { Vitor Kobiec } \\
\text { Fiamoncini, } \\
\text { MD }\end{array}$ & $\begin{array}{l}\text { Federal } \\
\text { University } \\
\text { of Parana }\end{array}$ & Author & $\begin{array}{l}\text { Study concept and design, } \\
\text { data analysis and } \\
\text { interpretation, and drafting of } \\
\text { the manuscript. }\end{array}$ \\
\hline $\begin{array}{l}\text { João Augusto } \\
\text { da Silva } \\
\text { Freitas, MD }\end{array}$ & $\begin{array}{l}\text { Federal } \\
\text { University } \\
\text { of Parana }\end{array}$ & Author & $\begin{array}{l}\text { Study concept and design, } \\
\text { data analysis and } \\
\text { interpretation, and drafting of } \\
\text { the manuscript. }\end{array}$ \\
\hline $\begin{array}{l}\text { Marcos } \\
\text { Christiano } \\
\text { Lange, MD, } \\
\text { PhD }\end{array}$ & $\begin{array}{l}\text { Federal } \\
\text { University } \\
\text { of Parana }\end{array}$ & Author & $\begin{array}{l}\text { Study concept and design, } \\
\text { data analysis and } \\
\text { interpretation, and drafting of } \\
\text { the manuscript. }\end{array}$ \\
\hline $\begin{array}{l}\text { Bernardo C. } \\
\text { de A. Teixeira, } \\
\text { MD }\end{array}$ & $\begin{array}{l}\text { Federal } \\
\text { University } \\
\text { of Parana }\end{array}$ & Author & $\begin{array}{l}\text { Study concept and design, } \\
\text { image analysis and } \\
\text { interpretation, and drafting of } \\
\text { the manuscript. }\end{array}$ \\
\hline $\begin{array}{l}\text { Edison M. } \\
\text { Novak, MD }\end{array}$ & $\begin{array}{l}\text { Federal } \\
\text { University } \\
\text { of Parana }\end{array}$ & Author & $\begin{array}{l}\text { Study concept and design, } \\
\text { data analysis and } \\
\text { interpretation, and drafting of } \\
\text { the manuscript. }\end{array}$ \\
\hline $\begin{array}{l}\text { Hélio A.G. } \\
\text { Teive, MD, } \\
\text { PhD }\end{array}$ & $\begin{array}{l}\text { Federal } \\
\text { University } \\
\text { of Parana }\end{array}$ & Author & $\begin{array}{l}\text { Study concept and design, data } \\
\text { analysis and interpretation, } \\
\text { study supervision, revision of } \\
\text { the manuscript, and final } \\
\text { approval. }\end{array}$ \\
\hline
\end{tabular}

\section{References}

1. Anagnostou T, Arvanitis M, Kourkoumpetis TK, et al. Nocardiosis of the central nervous system experience from a general hospital and review of 84 cases from the literature. Medicine 2014;93:19-32.

2. Saubolle MA, Sussland D. Nocardiosis: review of clinical and laboratory experience. J Clin Microbiol 2003;41:4497-4501. 


\section{Neurology}

\section{Teaching NeuroImages: The tetraplegic gardener: A case of CNS nocardiosis in an immunocompetent patient}

Victor de Britto Gadelha, Fábio A. Nascimento, Vitor Kobiec Fiamoncini, et al.

Neurology 2019;92; $2840-\mathrm{e} 2841$

DOI 10.1212/WNL.0000000000007663

This information is current as of June 10, 2019

\section{Updated Information \&} Services

\section{References}

Subspecialty Collections

\section{Permissions \& Licensing}

Reprints including high resolution figures, can be found at: http://n.neurology.org/content/92/24/e2840.full

This article cites 2 articles, 1 of which you can access for free at: http://n.neurology.org/content/92/24/e2840.full\#ref-list-1

This article, along with others on similar topics, appears in the following collection(s):

All Clinical Neurology

http://n.neurology.org/cgi/collection/all_clinical_neurology All Infections

http://n.neurology.org/cgi/collection/all_infections

Fungal infections

http://n.neurology.org/cgi/collection/fungal_infections

\section{MRI}

http://n.neurology.org/cgi/collection/mri

Spinal cord infection

http://n.neurology.org/cgi/collection/spinal_cord_infection

Information about reproducing this article in parts (figures,tables) or in its entirety can be found online at:

http://www.neurology.org/about/about_the_journal\#permissions

Information about ordering reprints can be found online:

http://n.neurology.org/subscribers/advertise

Neurology ${ }^{\circledR}$ is the official journal of the American Academy of Neurology. Published continuously since 1951, it is now a weekly with 48 issues per year. Copyright @ 2019 American Academy of Neurology. All rights reserved. Print ISSN: 0028-3878. Online ISSN: 1526-632X.

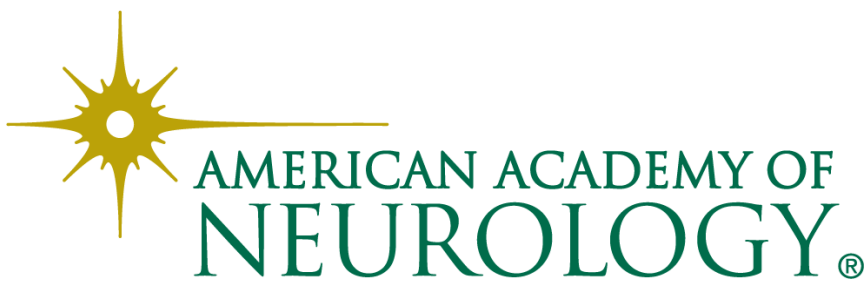

